\title{
Change in Tenure Pattern and Customary Land Practices among Igbo Community in Southeastern Nigeria
}

\author{
Emeka E.Obioha \\ Department of Social Anthropology and Sociology, National University of Lesotho, \\ Roma, Lesotho \\ E-mail:eeobioha@yahoo.com
}

KEYWORDS Tenurial Pattern. Customary Land Practices. Changes. Igbo. Nigeria

\begin{abstract}
Land to the Ibos of southeastern Nigeria is a property that has both religious, economic, political meaning. This conception held strongly until the era of colonialism when new cultural and economic values were introduced into the colonies. As in many African societies, Ibo society accepted some of the tenets of the colonial rules without force, but was forced to adopt some other measures through obnoxious legislations. Ibo society continuously remains helpless in reverting colonial masters' imposed legislations. However, as other aspects of the peoples' culture keep on changing those which relate to customary land laws are assumed to follow suit. Against this background, this study examines the changes that have occurred in various customary land regulations of the people of Awo-Idemili in Imo State, a rural community located at 33rd kilometers east of the River Niger. The study utilised the anthropological methods, namely Key Interview, Observations, and Archival Records in collecting its data. The study explains the changing tenure and land laws phenomenon from the conflict perspectives of Karl Marx and Hegel. The study reveals that most aspects of the land laws of the people including land pledging, communal ownership, land sales, inheritance procedure, and gift land among others have changed due to the emerging social and economic pressure on land in the area, coupled with increasing population pressure. The implications include the fact that people do not observe the previous culturally defined channels of acquiring and disposing of land in the community. However, the implementation of the Land Use Act 1978 in Nigeria has created some avenues to more people on land in Nigeria.
\end{abstract}

\section{INTRODUCTION}

The concept of land as it existed in the precolonial African societies has been affected considerably by colonial rule. With the inception of the colonial period, there was a drift in the popular perception of land by Africans as a result of the changing economic importance of land during this period. The utility of land was conceived and appreciated mainly from its economic dimension as opposed to the traditional conception of land as a social and religious entity. People began to see land as having economic potentials and predictable values. In this light, Dike (1983) has summed that the acquisition of money has opened up the possibility of an unlimited range of choice. According to him, unlike in the pre-colonial period when land was seen as a sacred entity, land in the new dispensation is no longer considered largely as a sacred and a religious commodity. Rather, it is now predominantly seen as a purely economic item. This change in the conception of land from the pre-colonial perspective to colonial perception generated some land problems and pressure on the customary land laws. Put more succinctly, this is to say that the introduction of colonial rule and the consequent change in the conception of land in Africa, as a result of the economic and legal attributes of colonialism have led to the emergence of new and previously unknown land problems. Due to the introduction of the English legal system, several aspects of the existing native, customary land law were undermined and made redundant.

Change in the value of land as a result of colonialism was brought about by the introduction of new economic system. Cash cropping, for instance replaced the African subsistence economic system of production, inorder to meet the demand for cash crops being the needs for the industrial development of western countries of Europe, who were the colonial masters in Africa then. The consequent increase in population, and the introduction of money economy contributed to the emergence of land problem in Africa. Colonialism brought about the emergence of urbanization and limiting of wars and epidemics. In the pre-colonial period in Nigeria, there were series of inter-tribal wars, epidemics and rural dwellings which inhibited population concentrations and explosion, but with colonialism, some of these inherent problems disappeared, giving rise to population increase 
and pressure on land. These new phases of development in Africa and the new economic system of agriculture (cash cropping) stimulated a need for more exploitation of lands, which changed the pre-colonial distribution of land from relative abundance to scarcity in supply. This created the need for scrambling for land as the most important means of acquiring more land. These new demands activated a chain of processes, which sought to threaten and undermine the integrity of the existing customary land laws. Another contributory factor was that the colonial authority could not bear the continuity of the existing customary rules. Hence, in Colson's opinion (1971) it was inevitable that the colonial governments should impinge upon land rights even where they accepted the obligation to preserve the existing rights and recognized local customs. Customary land laws are still applicable in Awo-Idemili, despite the influence of colonial rule on it. These laws are in some aspects changed and modified in different societies, to suit the society. Like the customary land laws, other aspects of the social systems of different African societies are undergoing a process of change. With particular reference to the Awo-Idemili, the study area, it is important at this juncture to note that the traditional cultures were the subject and victim of colonial rule, while, the contemporary practices and cultural traits are the products of the ensuing contact. In this regard, the contemporary culture in Awo-Idemili like in most other African contemporary cultures are viewed as being in continuous change and adaptations, which reflects the response and reactions to both internal and external influences of social change.

The present study aims at examining the nature and extent of change in the customary land law system in Awo-Idemili. In doing this, the attempt is to employ anthropological methods of field study and theoretical orientation in the understanding of the research problem. In the end, it is hoped that the present study will become relevant for an understanding of the process of social change particularly as it relates to land in contemporary African society in general and Awo-Idemili in particular.

\section{THEORETICAL FRAMEWORK}

In the course of the research the conflict perspective was used as models to examine the course of changes in customary land law in the area of study. As social structures appear to some anthropologists as capable of generating their own weakness of forces of change so does customary law. Following Karl Marx, conflict theorists take the view that social structures are capable of producing within themselves the elements of their suppression and change. Social change is not always an adjusting process; rather a change can be revolutionary, sudden and profound. It results from internal conflicts and contradictions, which include population pressure as a result of high birth rate and invention of ideas. In this case customary land law in the area of study is not an exception in this theory. Changes occur within its system as a result of some inherent contradictions in the society.

The change in customary land law is not entirely predicated on the mechanism of internal contradictions alone, rather partially as a result of exogenous factors of change. In this regard, Anthropologists, especially those of the neoevolutionary school of thought such as Julian Steward (1902-1975), Leslie White (1900-1975), and Marvin Harris (1897-1985) believe that social systems therefore are dynamic and responsive to a changing environment in many ways. Steward developed an ecological approach to cultural change that focused on the adaptation of individual cultures to specific environmental circumstances. He proposed that cultures in similar environment would tend to follow the same developmental process and sequences and formulate similar responses to their environmental challenges. He termed those cultural features most closely associated with subsistence practices the cultural core (McGee and Warms, 1996). This response often tends to have a profound impact on the whole system. How a social system's external environment affects the internal subsystems is viewed from the modernization theory perspective. This involves a continuous adjustment of the entire native customs to suit the adoption of new ideas. This framework explains the effect and the process of change in customary land law as a result of the introduction of English legal system in the area of study. This view is an emphasis on exogenous source of change, which eventually re-institutionalized the institution of customary land law.

However, the synthesis of customary land law in the area of study is based on a number of 
related propositions derived from the observations of the dynamics of social systems. First, it has been observed that the customary land law is connected in one way or another with other social structures. This inter-relationship is marked by contradictions between the elements of time and space dimension. Second, there is eternal mutability of all elements of the social system in the area of study, which land law is no exception. Third, the given social structure (customary land law) in the process of change turns to assimilate substances from its environment that contributes to its survival and development. Fourth, that the entire social mechanism is not lost, rather the dialectical negation consists of the fact that an aspect of the previous form is lost, and replaced by new form, the whole system in this case has transformed to a new stage in development. From the above framework, customary land law in the area of study has changed through generation with adaptive mechanism of selection and adoption.

\section{RESEARCH METHODOLOGY}

\section{Location of the Study}

Awo-Idemili, headquarter of Orsu Local government area of Imo State, Nigeria lies at latitude 5 degrees 49' $\mathrm{N}$ and longitude 6 degrees 56 'E. The town occupies the western extreme of old Orlu Province of Eastern Nigeria. On the north, the town is bounded by Anambra state, on the east it shares with other communities in Orsu local government area of Imo stare. It is also bounded on the south by Oru West local government of Imo state. Coming from Onitsha, the commercial hearth beat of Anambra state towards Owerri the capital city of Imo State, AwoIdemili situates approximately between kilometers four to six along Ihiala - Orlu road off Onitsha Owerri road. Awo-Idemili lies on the eastern lowlands of the River Niger drainage basin, about 33 kilometers from the river itself. Topographically, it is about $135-170$ meters above the sea level, dominated by gentle slopes which steppes down southwards. Awo-idemili situates in one of the highest population densities contiguous zone in Imo state and apparently the whole of Nigeria. It has a density of about 800 persons per square kilometer and an overall population of 20,000 inhabitants in the 1963 national census. The population of the town would have grown beyond the above figure at present both in the density and overall figure given an annual population growth rate of over $3 \%$ according to the unpublished breakdown of figures for Nigeria 2006 Population and Housing Census.

\section{Methods of Data Collection}

This study adopted the method of key informant interview to collect data on the customary rule of inheritance, and the general patterns of land acquisition and conveyance. The key informant interviewing technique was adopted to overcome the interpretation problem that might arise from the observations. This unstructured key informant interviewing technique was of great help during the research; due to its open system method that allows follow up questions to back up interviews. It also afforded the opportunity of exploring necessary knowledge grounds on the issue through persistent questions. The method was used during the research to get information about the pre-colonial customary land law structure and the sequence of change undergone. During the use of the unstructured key informant interviews as a result of individual perception of a particular event in different ways posed a problem. In order to overcome the problem, the method of use of written records was used for earlier comparative analysis of response.

In this case written records about the legend of origin and the geographical background of the study area were collected. The method also afforded the opportunity to cross examine the information collected about the history of origin of the study area through oral traditions and key informant interviewing.

The method of analysis employed for the research is the descriptive analytical method involving a critical examination and explanation of information and data collected during the fieldwork. Case studies are analysed by bringing out the implication of such cases in the study area within the realm of customary land law. Besides, each structural case data is analysed to project the aspect of changes on customary land laws in such situation and factors responsible. 


\section{PRESENTATION OF FINDINGS}

\section{Aspects of Changes in Tenure Pattern and Customary Land Law}

In the society under study some aspects of change in the "Ideal" practice of the customary land laws are discovered to have gone through modification. These include local rules and regulations guiding acquisition, ownership and use of land. The nature of such change, the factors that brought about the change and how such change has affected the culture of the people form the bases of presenting the responses of key informants.

Change in Land inheritance Procedure: Inherited lands are those transferred from an original person who dies to another person who is usually a member of the same family or lineage. Inheritance is referred to as "ekpe" among the Awo-Idemili people. Land may be inherited from a lineage or from non-lineage source. It is a lineage source when the piece of land inherited is originally a property that has passed through past generations, while non-lineage inheritance occurs when one inherited or transfers land that was hitherto not part of his lineage. According to one of the key informants, the aspect of the inheritance procedure, which stipulates the particular portion of land to be inherited by the beneficiaries of a deceased man, has changed. The informant noted that this change was not abrupt. Rather it was a gradual process of change of the old rule. In his view this change can be attributed to changes in the traditional settlement pattern, coupled with increase in population of individual families. According to him, at present, despite the customary rule there is no longer a strict practice whereby the first son(s) of a deceased man must live in the father's house or inherit his compound while the youngest son must inherit his mother's hut and the land immediately surrounding it. He stated that the prevailing practice is one where the first son usually decides to leave his father's compound for another plot of land so that his younger brother will inherit and make use of their father's abode. This happens often when the first son has acquired enough wealth to build himself another house.

Based on this data, certain analytical deductions can be made. The inheritance rule in Awo-Idemili that stipulates the particular portions and quantity of land to be inherited has gradually changed over the years. Eldest sons of deceased men now have increasingly taken the option of leaving their father's compound for their younger brothers, unlike during the precolonial period when the first son of a man automatically and willingly inherited his house after the death of the father.

The rule relating to the portion of land inheritable by youngest son(s) of the deceased man's wives also has been affected by some factors of change, such as colonialism, Christian religion and subsequently monogamy, which brought about, co-habitation of husbands and wives.

While documenting the nature of change in the system of land tenure and the customary laws related to it especially with respect to the rules of inheritance, the present study also attempted to identify the factors underlying these changes. One of these factors identified by the study is the increase in the indigenous population of AwoIdemili and corresponding increase in family population. Respondents repeatedly highlighted this factor as an important factor accounting for the change in customary land law. Additional evidence for population increase has been documented by Ekanem $(1972)$ in his appraisal of Nigerian Census of 1963, showed that the Ibo population has been on increase, from about 5.4 million in 1953 Census to 9.4 million in 1963 Census. Presently, there is no specific population figure that might be called an Igbo population figure after the 1963 population census. The 1991 and lately 2006 population and house census were based on state of residence, without request for ethnicity. However, using Imo State, the state where Awo-Idemili situates as the point of reference, it has a progressive population density increase of an average of 619 persons (1999-2005), which is the third most densely populated state after Lagos and Anambra States. It also has an annual percentage change of $3 \%, 6 \%, 9 \%, 12 \%$, $15 \%$, and $19 \%$ in the population density structure in 2000, 2001, 2002, 2003, 2004 and 2005 in that order (see NISER, 2005). With the above scenario of continuous increase in population without corresponding increase in the total piece if land available. It is then obvious that demand for land rises beyond the availability. One of the main implications of this is the incessant land disputes in among various villages and lineages in AwoIdemili. 
The most important consequence of such increase in population and family size has been the introduction of certain amendments to the customary land laws and the rule of inheritance so that the interest of everyone involved in any particular case would be well taken care of. This is therefore directed more or less to ensuring that the welfare of the dependents of a deceased are adequately considered in the distribution of his landed property. The amendments are not written but based on unwritten agreement within each family, household or lineage that have common claim to the same landed property.

The change in settlement pattern as a result of the practice of monogamy also accounts for the change in inheritance. In this case, the stipulation of the customary land law about where the youngest son is to inherit has been rendered impracticable as a result of the system of cohabitation after marriage, which means that a deceased man's widow will continue to live in his home. Also, the right is separate house for husband and his wife in a monogamous family, so that once the eldest son of a deceased man has inherited his house, there is no separate house belonging to the women, which the youngest sons can inherit. In most cases, at present, the eldest son of the deceased man would have acquired wealth and built his own house in another portion of land. Thus, what follows is that he does not come back to his father's house when his father dies.

Another case was conducted with one of the key informants, an elderly man who hails from the town. The interview was directed at finding out the nature and use of "oral will" in the distribution of the land of a deceased man. According to the respondent, the practice has changed from what obtains in the past whereby the customary rule prevailed over any individual's will concerning land inheritance. The informant gave information of a case involving a man who left a will of his death, which bequeathed the backyard of his house to one of his sons, who was neither the eldest, the second nor the third, which ordinarily could have been assigned to the eldest son by the provision of customary rule of inheritance. According to the informant, this is a great change in the customary rule of inheritance that guides where each son has his inheritance. He said that when the man died, this provision in his will raised a lot of problem and dispute in the family. Before the dispute could be settled, it was discovered that the son of the deceased man whom the deceased willed the portion of land to, had erected a concrete structure on the said land. The dispute was taken to the court where the case was decided in favour of the son whose claim was backed by the provision in the will. The elder (respondent) commented that the Amalas ${ }^{2}$ could not do any thing about the case since 1982 until the present time. In his view, he attributed the emergence of courts as judicial alternatives and increase in personal wealth as the contributory factors in this prevalence of will over customary land laws.

On the basis of the above response, it can be seen that the customary land inheritance rule which stipulates where the deceased sons will inherit after the death of the father has been affected by changes with the introduction of the English system of will. Thus, this system now co-exists side by side with the customary practice as against the previously dominant customary law that dictated and determined how individual land is to be inherited by the beneficiaries. Thus, individuals now have the freedom to determine to a large extent how their piece of land is to be disposed of by the use of will, which may be written or oral. This has brought about the dual existence of two systems of land laws operating presently in the study area.

This situation, which allows for dual operation of two inheritance laws, could be attributed to the emergence of English court as judicial alternative to the customary law system. Also, the increase in personal wealth of men in AwoIdemili has created a situation where such men now have the freedom irrespective of the customary rule, to allow any of their sons to build house even at the back of their own house, which is customarily a birth right of the eldest son. This represents a significant shift in the traditional inheritance rule.

Change in Right to Sale an Inherited Land: The third interview was with one of the chiefs in the town. The interview, among other things sought to find out the right of the individual to sell inherited land, which is contradictory to the customary law. According to the chief an individual has the right to dispose off his inherited land in exchange for money if he so wishes. The chief mentioned an instance where a man disposed off his inherited land for money, which is contrary to the customary inheritance 
rule. The kinsmen of the man tried to stop him from selling the land, but later failed, when the case was taken to court.

Based on the response, an inference can be made about the change in the inheritance rule which prohibits the sales of an inherited land by the inheritor. It implies that individuals can now sell their inherited land to solve other personal problems. In this case the law that prohibits the sales of inherited land is no longer strong as it used to be before colonialism. The change in this aspect of inheritance rule can be correlated with the shift in the economy of the study area from a largely non-monetary to a monetary economy which accompanied colonialism. Money is now seen as an important measure of value. This change has brought about pressures on individuals to sell their land as a means of providing for their monetary needs. Apart from the economic change, the introduction of certificates of right of occupancy ${ }^{3}$ issued by the state government has personalized the ownership of land by giving individual absolute freedom to sell their individually owned land.

Change in Land Pledging: Land pledging is a customary way of transferring land whereby the original owner of title to a particular piece of land uses the land to either borrow money from an individual or a group of people. The agreement is usually in two forms 1) a specific time may be given when the pledger would redeem his debt and take possession of his land back or 2) there may no specific time duration to redeem the pledge. It may be indefinite through year and generations. Land pledging in traditional AwoIdemili customs and practices is akin to present collateral system in the modern banking and financial institutions.

Data was also collected on a case, which illustrated the change in the practice of pledging of land. An informant reported a case of between a pledgee and his pledger, which was brought to the council of elders of the village for settlement. The pledgee who was the plaintiff took the pledger (the defendant) to court on a dispute over the developed portion of the pledged land by the pledgee. The plaintiff presented the case before the council of elders that the defendant has to pay him compensation on the developed part of the pledged land before he took it back from him. The council of elders resolved that defendant should pay compensation to the plaintiff but defendant refused to agree with the council's verdict about the compensation to be paid for the developed portion of the piece of land. The defendant instead further argued that the plaintiff supposed to forfeit all the improvements he had made on the pledged land in line with the customary land law of land pledging. Even despite the disagreement the council insisted that the defendant (pledger) had to pay compensation of some amount of money to the plaintiff for the developed land before he could take over his piece of land.

From the above, it can be seen that the aspect of customary land acquisition procedure that provides for the forfeiture of all improvements on a pledged land by the pledgee is usually giving way to where improvement on such land must be compensated. This change in land pledging rule according to the informant is due to change in the economic system, which has made it possible for the worth of improvement on pledged land to be valued in money worth.

Change in Land Gift and Acquisition: Land gift system was a common practice in Awo-Idemili up to the recent time. In this case the original owner of the title to land presents a parcel of land to another person without exchange of money or property. This act is usually a permanent one, which usually can not be reversed through generations. Among the AwoIdemili people, the practice is usually a voluntary and a benevolent action from a father to a daughter who is being given out in marriage. It may also be between siblings or intimate friends or other related persons.

Apart from the change pointed out in the customary land acquisition procedures of inheritance, and land pledging, information based on the interview suggests that there has been some changes in the rule that guide land gift as a method of land acquisition. One of the informants during the fieldwork narrated a case, which the grantee happened to have sold a gift land. The plaintiff (the grantor) was praying that the defendant should give him the money he collected from the person to whom he sold the land which he gave to him as a gift. This dispute lasted for a long time before the case was brought to the court. The defendant on the other hand maintained that the land belongs to him, that he had the right to sell it. The defendant agreed that the plaintiff gave him the land some time in the past when he helped the plaintiff (grantor) to fight his neighbours. The court decided that the 
defendant (grantee) had the right to dispose off the land in exchange for money and that the plaintiff has no right over the land.

On the basis of this, some analytical inferences could be made. Due to the emergence of modern courts as judicial alternative, a grantee can dispose off a land given to him as a gift. This represents a major change in the rule that prohibits the disposition of gift land in the customary law. As such the customary land law at present in Awo-Idemili has adopted the provision of the system of English land laws in relation to this practice.

Change in Kola Tenancy: Kola tenancy is similar to ordinary land lease, but the difference is that in the case of kola tenancy, the person who holds the land got it from the original title holder without paying any money. It is referred to as "Izi Ala" that means showing land. This process of interchange is usually between very close friend or families. The person who holds the tenancy has no title to the land and can neither transfer ${ }^{44}$ Transfer is conceptualized as giving out land to another person either by sale or gift or what ever means it nor erect any structure on it. In Awo-Idemili there have also been some changes in the rule that guides the customary land acquisition procedure based on Kola tenancy. This is illustrated by narrative of one of the key informants concerning land disputes between a kola tenant's successor and the grantor of the land to their father. According to one of the respondents, the land in dispute was given to the initial grantee because they were friends and it did not involve any monetary transaction whatever. After the death of his friend (grantee) the grantor wanted to withdraw the usufructural right over the land from the successors to the grantee. The grantee's successors resisted at a meeting to settle the case, rather, that the land belongs to their father. From the above, it is important to note that the withdrawal of usufructural right from grantees by the grantors is not automatic as it was in the past.

\section{Change in Communal Land Ownership}

Apart from changes in patterns of individual land acquisition and the customary rules guiding such acquisition, there have also been pressures on the rules guiding communal ownership of certain portions of land. During the fieldwork, an observation was made on the case concerning a chief in the study area who appropriated some portions of community land for his own personal use. Observation of the situation during the study shows that the chief trespassed into one of the piece of land that served as market square for the community. The chief converted this particular piece of land into a private school premise. This brought about a dispute between the chief on the one hand and the entire AwoIdemili community on the other land. During the time of the observation the community did not succeed in forcing the chief out of the land, so they took him to court. In deciding the case, the court granted the perpetuation of the chief's right to the land. Thus, the chief developed the community land, contrary to the customary law on the use of such land.

On the basis of the above case, an inference can be made that the rule concerning community ownership of land is beginning to yield to pressure from personal use. Seemly important factors underlying this undermining of customary laws concerning community ownership can be traced to the recent increase in personal wealth coupled with change in land use strategy. Due to the increase in personal wealth, individuals now use their wealth to influence the land by lobbying elders in the community to bend such laws in their favour. Also the change in land use strategy, whereby the community land is being converted to individually owned public utilities, is a development which specifically undermining the customary law relating to community land ownership.

\section{DISCUSSIONS}

This study documented several changes in some aspects of the customary rules relating to the procedure for the acquisition of land. For instance, the study shows that there has been change as well in the notion of the "inalienability nature of land. While in the past the customary land law entirely prohibits sales of land, presently some members of the community sell individually owned land in exchange for money to meet other needs. This change has also been noticed in other regions in Nigeria, showing that sales of land are no longer prohibited, as was the case during the pre-colonial period. Meek (1946) has once noted that people of Borno region of Nigeria have been selling and buying land as a result of the impact of modernism. In addition, he also 
identified sales of land as an aspect of change in the customary land law of the Dikwa people in Borno, which he said was due to colonialism.

As analysed from this study, the rule of inheritance specifying the actual portion of land to be inheritted has also witnessed some modifications in Awo-Idemili. From the findings of the research, these modifications are the results of changes in the settlement pattern of household from one where husband and wife live separately to one that encourages cohabitation. This change, as indicated earlier, has been an important source of change in the practical aspect of inheritance in the study area.

Apart from modifications resulting from changes in the settlement pattern, the increasing reduction of inheritable land has engendered a situation, which is characterized by changing attitude to inheritable land. Presently, most potential inheritors prefer to acquire their own land because they place more value on selfacquired properties and status than on those inherited. In this way, tension over inheritable land has become reduced in recent time. The study also identified some changes in the pattern of land pledging. The rule that if a pledgee develops a piece of pledged land he stands to lose such improvement when the land is redeemed has been somewhat modified. There is no more automatic forfeiture without the consent of the civil court, as against the customary land law stipulation of outright forfeiture by a pledgee in such instance. Presently in Awo-Idemili, compensations are paid by pledges in regard to any development on their pledged land to the pledgee before such land is redeemed.

Contemporarily, the practice of kola tenancy is no longer what it used to be in Awo-Idemili. This procedure is no longer widespread because of the experience of some landowners who faced difficulties in trying to redeem ownership to such land. The problem, which accounts for redundancy of kola tenancy results from the lack of documentation of the tenancy agreement which makes it difficult for grantors of such land to redeem their ownership.

Another issue of importance in relation to changing customary rules of land acquisition is concerned with the collapsing boundary between community and individual land. In AwoIdemili the research documented serious pressure on community land resulting from the desire of individual to convert such land to their personal use despite the attempt of the community to restrict such practices. In this way community's right to land is becoming exposed to the same pressures and alterations, which are the individual and family rights have faced. This is so because, as the available individual land diminishes, people become encouraged and desperate to acquire communally own land. This points to the fact that the laws defining what constitutes community land will expectedly become the next issue and area of urgent change.

The issue of change in customary land laws in Africa is a complex manifestation of the influence of both colonialism and the internal dynamic elaboration of different aspect of each society's culture. The data collected from AwoIdemili points to the fact that specific aspects of colonialism including the introduction of new legal system, monetization of the traditional economy, the change in some aspects of indigenous social relationship and several other changes and concomitants of these changes contributed in drawing about significant modifications in the traditional customary land laws of the community. Apart from extraneous factors, internal modifications such as the change in settlement patterns and the growth in population, and consequently family size have also contributed in engendering significant changes in the local customary laws. While the internal and external sources of change are difficult to separate, it is important to note that they have both played an important role in changing the attitude of local people to land. This change in attitude has itself become the force sustaining the current modifications in the customary land laws.

While it is important and legitimate to study other features of African culture, the issue of change will remain a most rewarding approach to the understanding of the present culture of the people. This is so because the theme of change enables one to understand how the past and the present people have merged to give the contemporary culture. It is especially beneficial to apply this approach to the study of the customary land laws system of a contemporary African society Awo-Idemili, because it provides a better understanding of not only the present cultural practices of the people, but also enhances the appreciation of the forces, which have contributed in changing the people's interactions with land as a case study of many other contemporary African societies. 


\section{CONCLUSION}

A general overview of this study shows that while there have been several changes in AwoIdemili customary land laws some important aspects of these laws have remained resilient. The changes include the sales of land, and the rule relating to the portion of land to be inherited. Also individuals now have freedoms to determine how their land will be distributed to their heirs through the use of will. In addition the rule of fortitude in the land pledging and that which deals with kola tenancy have been modified in the face of present realities.

Finally there have also been notable changes in communal ownership of land, which has resulted from the pressures on such land from individuals. These changes reflect the unique adaptation of the social organization of the community to externally induced changes, which accompanied the introduction of colonialism and the internal dynamics of the people's culture.

\section{NOTES}

1 Oral Wills are common thing that happen among the Awo-idemili people, thought it usually occurs in other societies. In Awo-Idemili, this type of will is referred to as "Ike Ekpe". In this event a person who is critically ill voluntarily administers his estate to the living by giving out some instructions on how his property would be disposed or distributed People present in this event may be the whole family members or individuals who may present themselves one after another to the person giving his will. Oral Wills are respected among the Igbos in general with little tendency of modification after the deceased.

2 Customary judges

3 Certificate of Occupancy is a legal document given to someone who has prema facia proves of ownership of a parcel of land by the government authority under the Land Use Act 1978. It may serve as a registration of title to land as it obtains in other countries.

4 Transfer is conceptualized as giving out land to another person either by sale or gift or what ever means.

\section{REFERENCES}

Biebuyck, D.: African Agrarian System. Oxford University Press, London (1963).

Bohannan, P.: Tiv Farm and Settlement: Oxford University Press, London (1953a).

Bohannan, P. Land Tenure and Land Tenure in an African Agrarian System.

Oxford University Press for International African Institute, London (1953b).
Brack, B.: Land Tenure and Social change in Bugusi. African Journal of Rural Society, 6(8): 68-88 (1961).

Chubb, L. T.: Ibo Land Tenure. Ibadan University Press, Ibadan (1961).

Coker, G. B. A.: Family Property among the Yoruba. Oxford University Press, London (1958)

Coker, G. B. A.: Property Law among the Yoruba. Oxford University Press, London (I961).

Colson, E.: Land Law and Land holding among Valley Tongg of Zambia. South Western Journal of Anthropology, 22: 78-93 (1966).

Colson, E.: The impact of Colonial Period on the definition of Land Rights in Colonial Africa: Oxford University Press, London (1971).

Dike, A.: Land Tenure System in Igboland. International Review of Ethnology and Linguistics. Anthropos, 78: 853-871 (1983).

Elias, T. O.: Nigeria Land Law and Custom. University Press, London. (1951a).

Elias, T. O.: Nature of African Customary Law. University Press, London (1951b).

Gluckman, M.: The Economy of Central Baroese Plai. Rhodes-Livingstone Paper, No. 7 (1941).

Gluckman, M. Essay on Lozi Land and Royal Property. Rhodes-Livingstone Paper, No. 10 (1943):

Gluckman, M.: Studies in African Land Tenure. African Studies, 3: 14 - 21 (1974).

Guliver, P.: Land Tenure and Social Change among the Nyakusa. East African Studies, 11: 67-91 (1958).

Guliver, P.: Land shortage, social change and social conflict in East Africa. Journal of Conflict Resolution, 5: 3-21 (1961).

Handy, E.S.C.: Religious Significance of Land. Royal African Society, 38: 55-67 (1939).

Jones, G. I.: Ibo Land Tenure. Africa, 19(4): 309-323 (1949).

Lloyd, P.C.: Yoruba Land Law. Oxford University Press, London (1962).

Mair, L.P.: Modern Development in African Land Tenure. Africa, 18: 189-202 (1948).

McGee, R. J and Warms, R. L.: Anthropological Theory: An Introductory History. Mayfield Publishing Company, California (1996).

Meek, C.K.: Land Law and Customs in the Colonies. London University Press, London (1946).

Meek, C.K.: Land Tenure and Land Administration in Nigeria and Cameroon. London University Press, London (1957).

Nigerian Institute of Social and Economic Research: Situation of Social Development in Nigeria: PublicPrivate Partnership in Nigeria Development. NISER, Ibadan (2005)

Obi, S. N.: Ibo Law of Property. Butterworth and Company, London (1963).

Olawoye, C. O.: Title to land in Nigeria. University of Lagos Press and Evans Brothers Limited, London (1974).

Oluyode, P.A.: Judicial Settlement of Boundary Disputes in Western Nigeria. Odua Journal of West African Studies, 1: 6-25. University of Ife Press, Ife (1971).

Price, W.: Land Tenure in Yoruba Provinces. Oxford University Press, London (1933). 